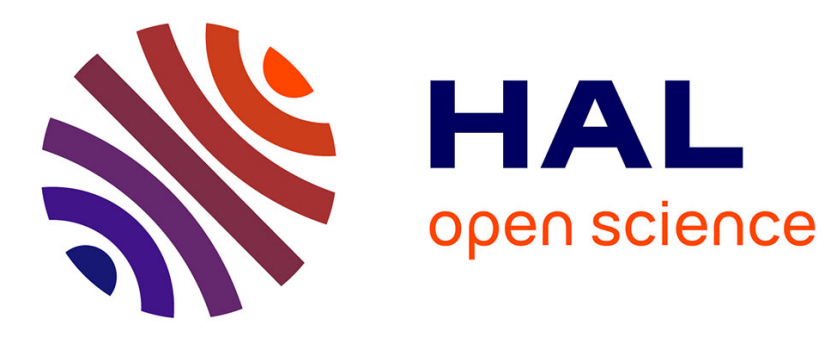

\title{
The first araripeneurine antlion in Burmese amber (Neuroptera: Myrmeleontidae)
}

Diying Huang, Dany Azar, Michael S. Engel, Romain Garrouste, Chenyang Cai, André Nel

\section{- To cite this version:}

Diying Huang, Dany Azar, Michael S. Engel, Romain Garrouste, Chenyang Cai, et al.. The first araripeneurine antlion in Burmese amber (Neuroptera: Myrmeleontidae). Cretaceous Research, 2016, 63, pp.1-6. 10.1016/j.cretres.2016.02.010 . hal-01288140

\section{HAL Id: hal-01288140 https: / hal.sorbonne-universite.fr/hal-01288140}

Submitted on 14 Mar 2016

HAL is a multi-disciplinary open access archive for the deposit and dissemination of scientific research documents, whether they are published or not. The documents may come from teaching and research institutions in France or abroad, or from public or private research centers.
L'archive ouverte pluridisciplinaire HAL, est destinée au dépôt et à la diffusion de documents scientifiques de niveau recherche, publiés ou non, émanant des établissements d'enseignement et de recherche français ou étrangers, des laboratoires publics ou privés. 
The first araripeneurine antlion in Burmese amber (Neuroptera: Myrmeleontidae)

Diying Huang ${ }^{\mathrm{a}}$, Dany Azar ${ }^{\mathrm{a}, \mathrm{b}}$, Michael S. Engel ${ }^{\mathrm{c}, \mathrm{d}}$, Romain Garrouste ${ }^{\mathrm{e}}$, Chenyang Cai $^{\mathrm{f}}$, André $\mathrm{Nel}^{\mathrm{e} *}$

${ }^{a}$ State Key Laboratory of Palaeobiology and Stratigraphy, Nanjing Institute of Geology and Palaeontology, Chinese Academy of Sciences, Nanjing, People's Republic of China

${ }^{\mathrm{b}}$ Lebanese University, Faculty of Sciences II, Department of Life and Earth Sciences, Fanar, Lebanon

c Division of Entomology, Natural History Museum, and Department of Ecology \& Evolutionary Biology, 1501 Crestline Drive - Suite 140, University of Kansas, Lawrence, Kansas 66045-4415, USA

${ }^{\mathrm{d}}$ Division of Invertebrate Zoology, American Museum of Natural History, Central Park West at 79th Street, New York, New York 10024-5192, USA

e Institut de Systématique, Évolution, Biodiversité, ISYEB - UMR 7205 - CNRS, MNHN, UPMC, EPHE, Muséum national d'Histoire naturelle, Sorbonne Universités, 57 rue Cuvier, CP 50, Entomologie, F-75005, Paris, France

${ }^{\mathrm{f}}$ Key Laboratory of Economic Stratigraphy and Palaeogeography, Nanjing Institute of Geology and Palaeontology, Chinese Academy of Sciences, Nanjing 210008, China

* Corresponding author. E-mail. anel@mnhn.fr

\section{ABSTRACT}

Burmaneura minuta gen. et sp. nov., the first araripeneurine antlion in amber, is characterized, described and compared with the modern and Mesozoic Myrmeleontidae. The precise 
position of the fossil within this group is debatable. Interestingly, despite a rather rich fossil record, all Mesozoic Myrmeleontidae belong to subfamilies that are not recorded in the Cenozoic, although this might merely reflect the artificiality of the classification as the extinct groups may be paraphyletic with respect to their younger counterparts (e.g., Araripeneurinae may very well be nothing more than a stem group of no classificatory value).

Keywords:

Insecta

Myrmeleontiformia

Araripeneurinae

gen. et sp. nov.

Burmese amber

Cenomanian

\section{Introduction}

The antlions, family Myrmeleontidae (Neuroptera: Myrmeleontiformia), are relatively scarce in the fossil record when compared to other Neuroptera. While there are a few species, some known only as larvae, from the Cenozoic (Statz, 1936; Engel and Grimaldi, 2007), it is during the Mesozoic that there is a more enriched record, albeit still comparatively meager. The estimate origin for (Ascalaphidae+Myrmeleontidae) is during the late Jurassic at around 153 Ma and around 134 Ma for the stem Myrmeleontidae (Winterton et al., 2010). The Lower Cretaceous Crato Formation in Brazil has revealed a nominally diverse fauna (Martins-Neto et al., 2007), and other antlions are known from the Lower Cretaceous of Israel, Mongolia, China (Ponomarenko, 1992; Dobruskina et al., 1997; Ren and Guo, 1996; Ren and Engel, 2008), and the Upper Cretaceous of Labrador, Canada (Rice, 1969). All of the Mesozoic 
antlions are represented by compression fossils, with a state of preservation that is always good, although Whalley (1980) reported a putative, fragmentary myrmeleontid from Lebanese amber. Stange (2004) provided an annotated list of the modern and fossil antlions, and advocated subfamilial status for the two Mesozoic groups Palaeoleontinae Martins-Neto, 1992 and Araripeneurinae Martins-Neto and Vulcano, 1989 (sometimes considered as separate families in Myrmeleontoidea), although monophyly has never been demonstrated for either one. Both are distinguished solely on the basis of putative plesiomorphies and should be reevaluated in a cladistic framework (something beyond the scope of the present contribution). Hiltherto no Myrmeleontinae have been recorded from the Mesozoic, nor have Myrmeleontidae been formally described from Cretaceous amber.

Here we provide the first formal description of an antlion in Burmese amber and based on a nearly complete adult (Fig. 1). This amber deposit has already produced a rather diverse neuropteran fauna, with described species of Berothidae, Rachiberothidae (sometimes considered a subfamily of the former), Mantispidae, Coniopterygidae, Psychopsidae, Berothidae, Nymphidae, Osmylidae, Dilaridae (Grimaldi et al., 2002; Engel and Grimaldi, 2008; Makarkin, 2015a,b; Huang et al., 2015), and undescribed material of Kalligrammatidae and Chrysopoidea is also known (pers. obs.). Indeed, Neuropterida as a whole are well represented in Burmese amber, with diverse snakeflies (Engel, 2002; pers. obs.) and various Sialidae (Engel and Grimaldi, 2008; pers. obs.).

\section{Material and methods}

The present specimen is preserved in a piece of relatively clear, yellow amber, and was ground and polished prior to examination and photography.

The fossil was studied and measured using incident and transmitted light with stereomicroscopes (Olympus SZX9 and Nikon SMZ 1500), as well as a Leitz Wetzlar 
binocular compound microscope. Further observations and microphotographs were taken using a Zeiss Discovery V20 stereo-microscope and a Zeiss Axio Imager Z2 light microscope with an attached digital camera (AxioCam HRc) respectively. Images were digitally compiled using Helicon Focus software, and arranged using Adobe Photoshop software. The taxonomic actions established in the present work are registered in ZooBank, and with the publication urn:1sid:zoobank.org:pub:F27A37BB-7B61-4EED-8E5C-9956C2E091FD. We have followed the wing venation terminology of Stange (1994), and the myrmeleontid classification as proposed by Stange (2004).

The Burmese fossils come from the Hukawng Valley in the northern state of Kachin, Myanmar (Burma). The specific mine from which the fossils originated cannot be determined as they were acquired from fossil traders, but these are generally around a series of villages such as Nojie Bum in the Hukawng Valley. A map of the area where the amber has been found is available in Dong et al. (2015). Historically, the age of burmite has been elusive, ranging from Miocene to an unspecified stage of the Cretaceous. Recently, an absolute age of $98.79 \pm 0.62 \mathrm{Ma}$ (earliest Cenomanian) was obtained for Burmese amber based on U-Pb dating of zircons (Shi et al., 2012). Nonetheless, this amber could be slightly older, as frequently amber pebbles from this locality underwent surface perforation, suggesting that the amber was already hardened when re-deposited. The history of this amber has been reviewed by various authors (see Cruickshank and Ko, 2003), and the deposit arguably contains perhaps the greatest diversity of inclusions among Cretaceous ambers (Grimaldi et al., 2002).

\section{Systematic palaeontology}

Family MYRMELEONTIDAE Latreille, 1802

Subfamily ARARIPENEURINAE Martins-Neto and Vulcano, 1989 
Genus Burmaneura gen. nov.

Type species: Burmaneura minuta sp. nov.

Diagnosis. Highly probable absence of sensory setae on pro- and mesofemora; pretarsal claws well developed, more than three times longer than width of apical tarsomere; wings narrow with a narrow area between branches of $\mathrm{CuA}$; forewing 1A not united with $\mathrm{CuP}$; area between $\mathrm{CuP}$ and posterior wing margin narrow; anal veins short; hypostigmatic cell present and elongate; base of Rs distant from wing base; presectoral crossveins in forewing absent; hind wing $\mathrm{CuA}$ running to hind margin and connected to MP2 by a simple crossvein.

Derivation of name. The generic name is a combination of Burma, colonial name for Myanmar and from which the fossiliferous amber gets its common and mineral names (i.e., burmite), and the Greek neuron meaning, "nerve" (a reference to the network of wing veins), a frequent termination for myrmeleontid names, such as in Araripeneura, type genus of the subfamily. The gender of the name is feminine.

Remarks. Among those Mesozoic myrmeleontids of uncertain affinities, Burmaneura differ from Choromyrmeleon Ren and Guo (two Mesozoic species) in the presence of a pronounced antennal club and the less-developed cubital area (Ren and Guo, 1996; Ren and Engel, 2008). Cretoleon Ponomarenko differ from Burmaneura in the strongly proximal position of the base of Rs and the broad cubital area of the forewing (Ponomarenko, 1992).

\section{Burmaneura minuta sp. nov.}

Figs. 1-4

Derivation of name. The specific epithet is taken from the Latin, minutus, meaning, "small", and as a reference to the generally diminutive size of the insect. 
Holotype. NIGP163428 (a complete body, with four wings, one foreleg, one mid leg, an incomplete hind leg, and antennae attached. The apical portions of the wings are missing); amber, lowermost Cenomanian; Hukawng Valley, Kachin, northern Myanmar; deposited in the Nanjing Institute of Geology and Paleontology, China.

Diagnosis. As for the genus (vide supra).

Description. Head transverse, $0.8 \mathrm{~mm}$ long, $1.3 \mathrm{~mm}$ wide; antenna short, $2.2 \mathrm{~mm}$ long, with 22 antennomeres and a pronounced antennal club formed of apical seven flagellomeres, broad and flat, $0.6 \mathrm{~mm}$ long, $0.35 \mathrm{~mm}$ wide; antennal bases close to compound eye margin; compound eyes entire and hemispherical, greatly exophthalmic; ocelli absent.

Pronotum broadly triangular, as long as wide, $0.5 \mathrm{~mm}$ long, $0.5 \mathrm{~mm}$ wide; pronotal articulation close to mesothoracic spiracle; meso- + metathorax $1.4 \mathrm{~mm}$ long, $0.7 \mathrm{~mm}$ wide.

Wings hyaline, not pigmented; preserved part of forewing ca. $6 \mathrm{~mm}$ long, $2.6 \mathrm{~mm}$ wide; costal area $0.2 \mathrm{~mm}$ wide, narrow compared to intraradial width; costal veinlets and humeral vein all simple; costal area after fusion of Sc with RA not preserved; five preserved crossveins between RA and Rs+MA; MA appearing as an oblique vein between M and R, 0.9 $\mathrm{mm}$ from wing base; no presectoral crossveins; Rs+MA origin $2.9 \mathrm{~mm}$ from wing base; distal portion of area of Rs not preserved, exact number of branches of Rs unknown; first branch (MA) of Rs+MA distant from origin of Rs; MP simple along preserved portion; only one row of crossveins in area between $\mathrm{CuA} 1$ and posterior wing margin; cubital fork $3.7 \mathrm{~mm}$ from wing base; $\mathrm{CuA} 2$ rather short, ca. $0.8 \mathrm{~mm}$ long; $\mathrm{CuP}$ with only one row of narrow cells between it and posterior wing margin; $\mathrm{CuP}$ terminating in basal half of wing, $3.8 \mathrm{~mm}$ from wing base; $1 \mathrm{~A}$ closely parallel to $\mathrm{CuP}$ and not fusing, not pectinate, terminating on posterior wing margin, $1.4 \mathrm{~mm}$ from wing base; $2 \mathrm{~A}$ and $3 \mathrm{~A}$ reduced; $2 \mathrm{~A}$ basally parallel to $1 \mathrm{~A}$, not bent at sharp angle toward $3 \mathrm{~A}$. 
Hind wing elongate and rather narrow, preserved portion $8.2 \mathrm{~mm}$ long and $1.7 \mathrm{~mm}$ wide; a series of long setae visible on posterior margin; pterostigma inconspicuous; costal area similar to that of forewing but narrower, $0.1 \mathrm{~mm}$ wide; a long hypostigmastic cell below Sc+RA, outer gradate series of crossveins absent; only one presectoral crossvein close to base of Rs; MA reduced, not visible at wing base; base of Rs $3.0 \mathrm{~mm}$ from wing base; branching of Rs similar to that of forewing with first branch distant from Rs base; first crossvein between Rs and MP slightly sinuous; fork of MP into MP1 and MP2 close to wing base; CuA rather short, $2.0 \mathrm{~mm}$ long, emitting only two short posterior branches; $\mathrm{CuP}$ and anal veins present but reduced; protibia $0.6 \mathrm{~mm}$ long, protarsus $0.6 \mathrm{~mm}$ long; no clavate setae on profemur; protibial spurs long; mesofemur $0.7 \mathrm{~mm}$ long, mesotibia $0.7 \mathrm{~mm}$ long; sensory setae absolutely not visible, probably absent, on pro- and mesofemora; pretarsal claws well developed, more than three times longer than width of apical tarsomere; arolium absent. Abdomen strongly deformed as preserved, $3.2 \mathrm{~mm}$ long, $0.9 \mathrm{~mm}$ wide, individual segments beyond petiolar segment apparently transverse; genitalia not visible.

\section{Discussion}

Following the system of Stange (1994), Burmaneura would fall within the Ascalaphidae + Myrmeleontidae owing to the following characters: arolium absent; antenna clubbed (character 2, state 2); and pronotal articulation close to mesothoracic spiracle (maybe articulated with it, character 5, state 1). Burmaneura lack an Eltringham's organ at the base of the hind wings (the presence of which is putatively apomorphic for male Myrmeleontidae), but the holotype is likely a female and so this does not exclude the genus from the family. The genus has an elongate hypostigmastic cell in at least the hind wing, and this is an apomorphy of the Myrmeleontidae when compared to the related family Ascalaphidae. 
The main difficulty for defining affinities of Burmaneura among the Myrmeleontidae is the lack of a phylogenetic hypothesis for the family, and clear apomorphies for subgroups recognized therein. Following Stange's (2004) key to the Myrmeleontidae (including the modern Stilbopteryginae and the two fossil groups Palaeoleontinae and Araripeneurinae), Burmaneura would not fall in the Palaeoleontinae owing to the presence of an elongate hypostigmatic cell (the absence of which is plesiomorphic and palaeoleontines are likely nothing more than a grade of stem-group Myrmeleontidae). The genus would fall within the strictly Mesozoic Araripeneurinae due to the absence of presectoral crossveins in the forewing, while modern myrmeleontids have at least one presectoral crossvein. Again, the subfamily is defined on the absence of crown-group myrmeleontid apomorphies, suggesting that Araripeneurinae, like the palaeoleontines, are not a natural group and constitute a grade. The absence of presectoral crossveins could be interpreted as a reduction owing to smaller sizes among the araripeneurines, but the size differences are not that great and miniaturization usually is accompanied by far greater reductions in general venation, not observed in the known Araripeneurinae. Accordingly, the available evidence tends to suggest that Palaeoleontinae and Araripeneurinae collectively form a grade to more typical, crown-group Myrmeleontidae, and potentially obscuring important phylogenetic trends within the family behind an artificial nomenclatural edifice. This possibility stresses the need for future cladistic work incorporating both living and fossil Myrmeleontidae and in the hopes of establishing and newly circumscribing monophyletic subfamilies.

All of the known Araripeneurinae are relatively poorly understood and based on incomplete compressions from the Lower Cretaceous Crato Formation in Brazil. Burmaneura differ greatly from all Araripeneurinae, except Blittersdorffia volkheimeri Martins-Neto and Vulcano, 1989, in the narrow wings with a distinctly narrower area between the branches of CuA (Martins-Neto and Vulcano, 1989; Martins-Neto, 2000; Martins-Neto and Rodrigues, 
2010). Species of Blittersdorffia differ from Burmaneura in that the base of Rs is closer to the wing base, crossveins are numerous in the area between RA and Rs, $\mathrm{CuAb}$ and $1 \mathrm{~A}$ are longer, and the area between $\mathrm{CuP}$ and the posterior wing margin is broader. The body structures of Blittersdorffia are poorly known, its legs are unknown, its pronotum seems to be rather narrow and small, and its antenna is clubbed. The hindwing seems to be unknown in Blittersdorffia.

The potential absence of sensory setae on the pro- and mesofemora, the welldeveloped pretarsal claws that are more than three times longer than the width of the apical tarsomere, all suggest a placement for Burmaneura near to the Stilbopteryginae or to the Palparinae, the latter being potentially basal, rather than close to the Myrmeleontinae. The presence of sensory setae on the femora is a putative apomorphy of the Myrmeleontinae according to Stange (1994), although this requires testing in a cladistic framework. The hind wing $\mathrm{CuA}$ running to the hind margin and connected to vein MP2 by a simple crossvein is a plesiomorphic character present in the Araripeneurinae and the Myrmeleontinae, but not present in the Stilbopteryginae and the Palparinae, and Burmaneura, not surprisingly, does not fall satisfactorily in any of the modern myrmeleontid subfamilies as they are currently defined.

\section{Concluding remarks}

The discovery of Burmaneura minuta expands our knowledge of Mesozoic myrmeleontid diversity and provides unique information owing to its preservation in amber. We provisionally include Burmaneura in the Araripeneurinae, noting that the definition of this subfamily, as well as the Palaeoleontinae, is less than satisfactory and both are based on the absence of more typical, 'myrmeleontid' traits. A phylogenetic analysis of the myrmeleontid groups will be necessary to refine our understanding of the position of the new genus, as well as the relationships of all Mesozoic myrmeleontoids. 


\section{Acknowledgments}

We sincerely thank the two anonymous referees for their very useful comments on the first version of the paper. This project has been supported by the National Basic Research Program of China (2012CB821903), and is a contribution of the Division of Entomology, University of Kansas Natural History Museum.

\section{References}

Cruickshank, R.D., Ko, K., 2003. Geology of an amber locality in the Hukawng Valley, northern Myanmar. Journal of Asian Earth Sciences 21, 441-455.

Dobruskina, I.A., Ponomarenko, A.G., Rasnitsyn, A.P., 1997. Fossil insects from Israel. Paleontological Journal 31, 528-533.

Dong, F., Shih, C.-K., Ren, D., 2015. A new genus of Tanyderidae (Insecta: Diptera) from Myanmar amber, Upper Cretaceous. Cretaceous Research 54, 260-265.

Engel, M.S., 2002. The smallest snakefly (Raphidioptera: Mesoraphidiidae): a new species in Cretaceous amber from Myanmar, with a catalogue of fossil snakeflies. American Museum Novitates 3363, 1-22.

Engel, M.S., Grimaldi, D.A., 2007. The neuropterid fauna of Dominican and Mexican amber (Neuropterida: Megaloptera, Neuroptera). American Museum Novitates 3587, 1-58.

Engel, M.S., Grimaldi, D.A., 2008. Diverse Neuropterida in Cretaceous amber, with particular reference to the paleofauna of Myanmar (Insecta). Nova Supplementa Entomologica 20, 186.

Grimaldi, D.A., Engel, M.S., Nascimbene, P.C., 2002. Fossiliferous Cretaceous amber from Myanmar (Burma): its rediscovery, biotic diversity, and paleontological significance. American Museum Novitates 3361, 1-72. 
Huang, Di-ying, Azar, D., Cai, Chen-yang, Garrouste, R., Nel, A., 2015. The first Mesozoic pleasing lacewing (Neuroptera: Dilaridae). Cretaceous Research 56: 274-277.

Makarkin, V.N., 2015a. A new genus of the mantispid-like Paraberothinae (Neuroptera: Berothidae) from Burmese amber, with special consideration of its probasitarsus spine-like setation. Zootaxa 4007, 327-342.

Makarkin, V.N., 2015b. A remarkable new genus of Mantispidae (Insecta, Neuroptera) from Cretaceous amber of Myanmar and its implications on raptorial foreleg evolution in Mantispidae: a comment. Cretaceous Research 52, 423-424.

Martins-Neto, R.G., 2000. Remarks on the Neuropterofauna (Insecta, Neuroptera) from the Brazilian Cretaceous with keys for the identification of the known taxons. Acta Geologica Hispanica 35, 97-118.

Martins-Neto, R.G., Heads, S.W., Bechly, G., 2007. Neuropterida: snakeflies, dobsonflies and lacewings. In: Martill, D., Bechly, G., Loveridge, R. (Eds.), The Crato fossil beds of Brazil: Window into an ancient world. Cambridge University Press, Cambridge, pp. 328-340.

Martins-Neto, R.G., Rodrigues, V.Z., 2010. New neuropteran insects (Osmylidae, Palaeoleontidae, Araripeneuridae and Psychopsidae) from the Santana Formation, Early Cretaceous NE Brazil. Gaea, Journal of Geoscience 6, 1-8.

Martins-Neto, R.G., Vulcano, M.A., 1989. Neuropteros (Insecta, Planipennia) da Formação Santana (Cretáceo Inferior), Bacia do Araripe, Nordeste do Brasil. 2. Superfamilia Myrmeleontoidea. Revista Brasiliera de Entomologia 33, 367-402.

Ponomarenko, A.G., 1992. [New lacewings (Insecta, Neuroptera) from the Mesozoic of Mongolia]. Trudy Sovmestnaia Sovetsko-Mongol'skaia Paleontologicheskaia Ekspeditsiia [Transactions of the Joint Russian-Mongolian Paleontological Expedition] 41, 101-111 (in Russian). 
Ren, D., Engel, M.S., 2008. A second antlion from the Mesozoic of northeastern China (Neuroptera: Myrmeleontidae). Alavesia 2, 183-186.

Ren, D., Guo, Z.-G., 1996. On the new fossil genera and species of Neuroptera (Insecta) from the Late Jurassic of northern China. Acta Zootaxonomica Sinica 21, 461-479.

Rice, H.M.A., 1969. An antlion (Neuroptera) and a stonefly (Plecoptera) of Cretaceous age from Labrador, Newfoundland. Geological Survey of Canada Paper 68-65: 1-11.

Shi, G., Grimaldi, D.A., Harlow, G.E., Wang, J., Wang, J., Yang, M., Lei, W., Li, Q., Li, X., 2012. Age constraint on Burmese amber based on U-Pb dating of zircons. Cretaceous Research 37, 155-163.

Stange, L.A., 1994. Reclassification of the New World antlion genera formerly included in the tribe Brachynemurini (Neuroptera: Myrmeleontidae). Insecta Mundi 8, 67-119.

Stange, L.A., 2004. A systematic catalog, bibliography and classification of the world antlions (Neuroptera: Myrmeleontidae). Memoirs of the American Entomological Institute 74, 1-565. Statz, G., 1936. Über neue Funde von Neuropteren, Panorpaten und Trichopteren aus den tertiären Schiefern von Rott am Siebengebirge. Decheniana Verhandlungen des Naturhistorischen Vereins der Rheinlande und Westfalens (A) 93, 208-255.

Whalley, P.E.S., 1980. Neuroptera (Insecta) in amber from the Lower Cretaceous of Lebanon. Bulletin of the British Museum (Natural History) Geology 33, 157-164.

Winterton, S.L., Hardy, N.B., Wiegmann, B.M., 2010. On wings of lace: phylogeny and Bayesian divergence time estimates of Neuropterida (Insecta) based on morphological and molecular data. Systematic Entomology 35, 349-378. 
Fig. 1. Burmaneura minuta gen. et sp. nov., holotype NIGP163428, photographs of general habitus. A, dorsal view; $\mathrm{B}$, ventral view (scale bars $=1 \mathrm{~mm}$ ).

Fig. 2. Burmaneura minuta gen. et sp. nov., holotype NIGP163428. A, photograph of head and pronotum; B, photograph of antenna (scale bars $=0.5 \mathrm{~mm})$.

Fig. 3. Burmaneura minuta gen. et sp. nov., holotype NIGP163428. A, photograph of forewing base; $\mathrm{B}$, photograph of hindwing base (scale bars $=0.5 \mathrm{~mm}$ ).

Fig. 4. Burmaneura minuta gen. et sp. nov., holotype NIGP163428. A, drawing of forewing base; $\mathrm{B}$, drawing of hindwing base (scale bars $=1 \mathrm{~mm}$ ). 


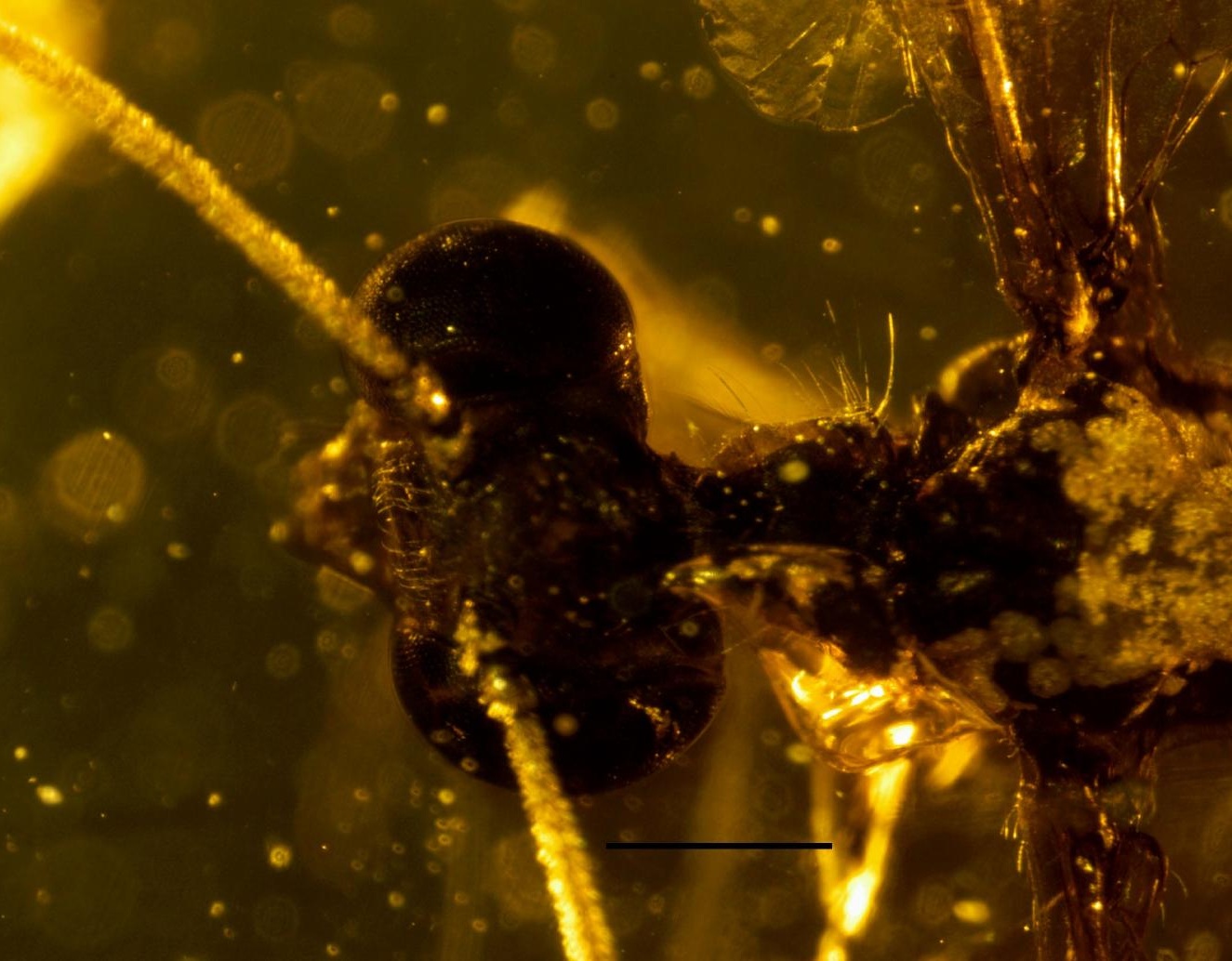




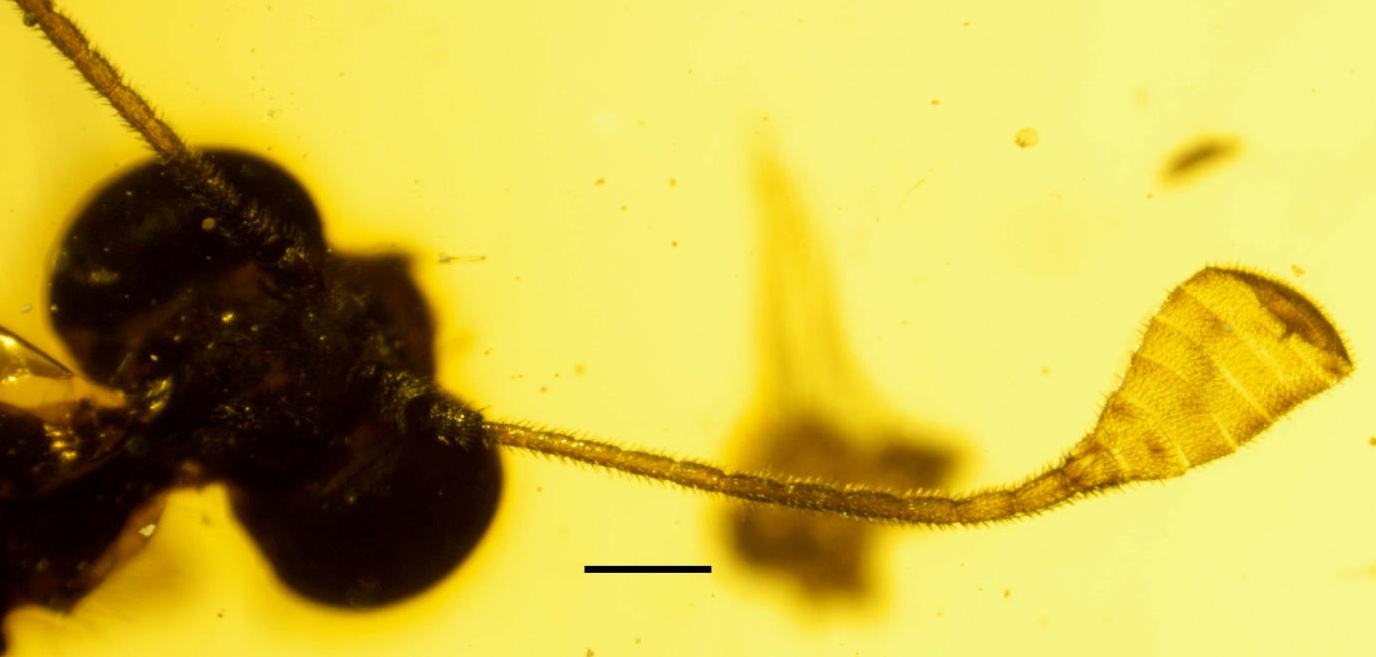




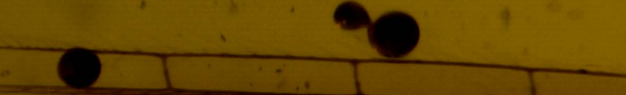

MP1

MP2

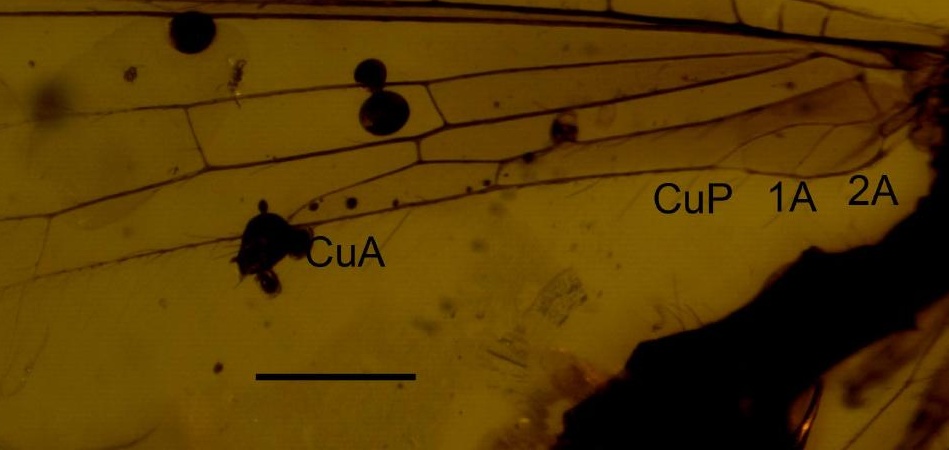




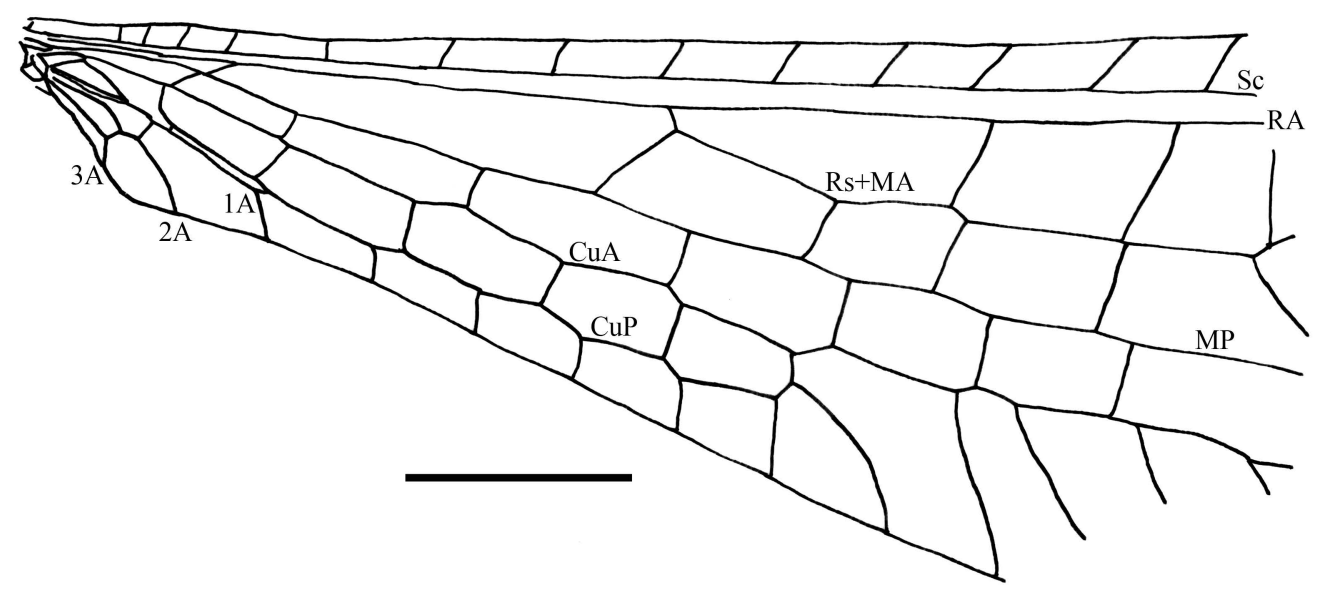




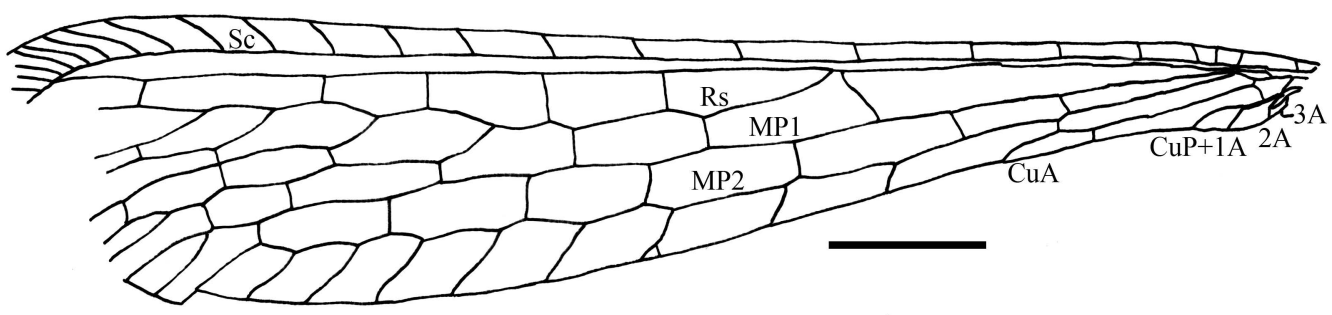

